\title{
Sero-epidemiological and reproductive survey for alphaherpesvirus infections in horses in the state of Pernambuco, Brazil
}

\section{Inquérito soro-epidemiológico e reprodutivo associado à infecção por alfaherpesvírus em equinos no estado de Pernambuco, Brasil}

\author{
Talita D'Paula Tavares Pereira Muniz ${ }^{1 *}$; Maria do Carmo Custódio de Souza \\ Hunold Lara²; Eliana Monteforte Cassaro Villalobos²; José Wilton Pinheiro Junior; \\ Ewerton Renner Gomes de Oliveira ${ }^{4}$; Gustavo Ferrer Carneiro ${ }^{3}$
}

\section{Highlights:}

There is a high number of farms with at least one reactive horse.

Four reproductive abnormalities were associated with herpetic infection in horses.

Biological reproductive techniques involved in natural mating are associated with herpetic infections.

\begin{abstract}
Equine alphaherpesvirus is a major pathogen that causes respiratory disorders, abortion, neurological syndromes, and perinatal mortality in horse populations worldwide. The aim of this study was to determine whether the occurrence of anti-alphaherpesvirus antibodies is correlated to reproductive abnormalities in horses in the state of Pernambuco, Brazil. The virus neutralization was carried out in 322 serological samples from unvaccinated horses from 42 farms located in 16 municipalities in the Microregion of the Vale do Ipojuca, Pernambuco, Brazil. Of these horses, 23.3\% (75/322; 95\% CI: 18.9-28.4\%) were found to be reactive to anti-alphaherpesvirus antibodies. In addition, $61.9 \%(26 / 42)$ of farms had at least one reactive animal, with an inter-herd variation of $5 \%$ to $100 \%$. With regard to reproductive rates, herpetic infection was associated with the use of biological reproductive techniques such as artificial insemination (AI) and embryo transfer (ET), which uses natural mating $(\mathrm{p}=0.003)$; history of perinatal mortality $(p=0.004)$; birth interval greater than two years $(p=0.003)$; and reproductive seasonality of mares with irregular cycles in the herd $(p=0.041)$. This is the first report on the identification of horses reactive to anti-alphaherpesvirus antibody in the state of Pernambuco, Brazil. From the results obtained, the adoption of prophylactic measures such as vaccination is suggested in order to prevent infection in susceptible animals and to reduce the viral load excreted by animals with quiescent infection.
\end{abstract}

Key words: Abortion. Equid alphaherpesvirus. Virus neutralization. Prophylaxis.

\section{Resumo}

O alfaherpesvírus equino é um importante agente patogênico causador de distúrbios respiratórios, aborto, síndrome neurológica e mortalidade perinatal em populações de equinos em todo o mundo.

\footnotetext{
1 Discente, Curso de Mestrado, Programa de Pós-Graduação em Ciência Animal Tropical, Universidade Federal Rural de Pernambuco, UFRPE, Recife, PE, Brasil. E-mail: talitadpaula@outlook.com

2 Pesquisadoras, Instituto Biológico, IB, São Paulo, SP, Brasil. E-mail: lara@biologico.sp.gov.br; villalobos@biologico.sp.gov.br

3 Profs., Programa de Pós-Graduação em Ciência Animal Tropical, UFRPE, Recife, PE, Brasil. E-mail: wiltonjrufrpe@gmail.com; carneirogustavo1@gmail.com

4 Discente, Graduação em Medicina Veterinária, UFRPE, Garanhuns, PE, Brasil. E-mail: ewerton_cumaru@hotmail.com

* Author for correspondence
} 
O objetivo deste trabalho foi determinar a ocorrência de anticorpos anti-alfaherpesvírus e relacionar às alterações reprodutivas em equinos no estado de Pernambuco, Brasil. A vírus neutralização foi realizada em 322 amostras sorológicas de equinos não vacinados, provenientes de 42 propriedades de 16 municípios pertencentes à Microrregião do Vale do Ipojuca, Pernambuco, Brasil. Observou-se uma ocorrência de 23,3\% (75/322; IC 95\%:18,9-28,4\%) de equinos reagentes à pesquisa de anticorpos antialfaherpesvírus. Além disso, 61,9\% (26/42) das propriedades possuíam pelo menos um animal reagente, com variação inter-rebanho de 5 a $100 \%$. Em relação aos índices reprodutivos, associou-se à infecção herpética a utilização de biotécnicas reprodutivas, como a inseminação artificial (IA) e a transferência de embriões (TE), com a monta natural $(\mathrm{p}=0,003)$; histórico de mortalidade perinatal $(\mathrm{p}=0,004)$; intervalo entre partos superior a dois anos $(\mathrm{p}=0,003)$; e sazonalidade reprodutiva de éguas com ciclos irregulares no rebanho $(\mathrm{p}=0,041)$. Este é o primeiro relato de detecção de equinos reagentes à pesquisa de anticorpos anti-alfaherpesvírus no estado de Pernambuco, Brasil. A partir dos resultados obtidos, sugere-se a adoção de medidas profiláticas como a vacinação, a fim de prevenir a infecção nos animais suscetíveis e reduzir a carga viral excretada nos animais com infecção quiescente.

Palavras-chave: Aborto. Equid alphaherpesvirus. Vírus neutralização. Profilaxia.

Significant economic power is attributed to equideoculture. It represents an important Brazilian agribusiness sector with revenues around $\mathrm{R} \$ 16$ billion per year, while generating 610,000 direct jobs and 2,430 indirect jobs Ministério da Agricultura, Pecuária e Abastecimento [MAPA, 2016]. Given the significant production of horses in Brazil, it is vital to sustain a harmonious balance between supplying high quality food to ensure healthy and consistent genetics and proper sanitary and reproductive management in order to obtain the intended results in terms of the performance of each animal (Beck \& Cintra, 2011).

Herpetic infection is considered to be one of the most detrimental diseases to equine breeding, especially when outbreaks of abortions occur (Grinde, 2013). Herpesviruses have an enveloped double-stranded linear DNA belonging to the Herpesviridae family, which are subdivided into three subfamilies: alpha, beta, and gamma. Alphaherpesviruses primarily affect mammals and are able to establish latency in many cell types while encoding chemokines that block the neutrophil response of the affected individual. This ensures the natural spread among susceptible individuals and the respective maintenance in the host (Penkert \& Kalejta, 2011).

A number of environmental and host-related factors including age, physical condition, and immune status, can be associated with the severity of the respective clinical disease, especially when secondary infections occur (Ma, Azab, \& Osterrieder, 2013). The source of infection in equine herd's ranges from animals with clinical infections, including nasal, uterine, and vaginal secretions, as well as fetuses and fetal appendages of abortions caused by equine herpesvirus type 1 (EHV-1), to subclinical sources with latent infections. Although venereal transmission in horses is still unclear, stallions are often unvaccinated, thereby endangering the herd's immunological protection by spreading the virus through nasal secretions or semen (Walter et al., 2012). In pregnant females, infection from more virulent and non-neuropathogenic strains can result in severe vasculitis in pregnant uteri, which can cause abortions in the last trimester of pregnancy (Gardiner et al., 2012).

There are several studies in the literature on herpetic infections, from neurologicalmanifestations to outbreak cases of abortions or perinatal mortality in several Brazilian states (Aguiar et al., 2008; Cunha et al., 2009; Alencar-Araripe et al., 2014). However, data on the occurrence of herpetic infections in horses in the state of Pernambuco have not been published. Given the high financial value of these animals, particularly their byproducts, it is of great importance to carry out epidemiological studies in order to gain insight on the occurrence and behavior 
of the disease in this region. Therefore, the aim of this study was to determine the occurrence of antialphaherpesvirus antibodies and its correlation with reproductive abnormalities in horses in the state of Pernambuco, Brazil.

A cross-sectional study was conducted in 42 farms distributed across the 16 municipalities of the microregion of the Vale do Ipojuca, Pernambuco, Brazil. For the occurrence study, a prevalence of 41.2\% (Alencar-Araripe et al., 2014) was considered, with a confidence interval of $94 \%$ and a statistical error of $6 \%$. These parameters resulted in a minimum sample number of 260 animals. A total of 322 blood samples were collected from unvaccinated horses against male and female herpetic infection from a variety of breeds, from December 2016 to September 2017. The selection of the farms was based on convenience, as they were selected according to the availability of the owners at the place and time of the data collection.

Prior to the collection of the biological material, an investigative questionnaire was administered with questions regarding reproductive history and the hygiene and sanitary management of the farm. The variables analyzed were as follows: gender; species; breeding system; region; farm type; purpose of horse breeding; horse breed; veterinary assistance; volume supplied; access to mineral salt; water source; equine herpesvirus vaccine; quarantine; destination of miscarried and placental fetuses; cleaning of stalls, troughs and feeders; reproductive techniques; cases of abortions at the farm; cases of perinatal mortality; fertility rate; average gestation time; reproductive seasonality; birth interval; and assisted deliveries (Table 1).

Table 1

Univariate analysis of significant variables associated with the occurrence of reactivity to anti-alphaherpesvirus antibodies in horses in the state of Pernambuco, Brazil, between December 2016 and September 2017

\begin{tabular}{ccc}
\hline Variable & N & VN Positive (\%) \\
\hline Gender & 159 & $42(26.4 \%)$ \\
Female & 163 & $33(20.2 \%)$ \\
Male & & \\
Species & 283 & $59(20.8 \%)$ \\
Horses & 22 & $14(63.6 \%)$ \\
Horses and mules & 17 & $2(11.8 \%)$ \\
Horses and donkeys & & \\
Breeding System & 136 & $27(19.9 \%)$ \\
Intensive & 136 & $38(27.9 \%)$ \\
Semi intensive & 50 & $10(20.0 \%)$ \\
Extensive & & $8(22.2 \%)$ \\
Purpose of the horse breeding & 36 & $36(21.2 \%)$ \\
Reproduction & 170 & $31(27.0 \%)$ \\
Sports & 115 & - \\
Sports + Reproduction & 1 & $21(15.3 \%)$ \\
Recreation & &
\end{tabular}


continuation

$\begin{array}{ccc}\text { Haras } & 184 & 53(28.8 \%) \\ \text { Region } & & \\ \text { Rural } & 273 & 67(24.5 \%) \\ \text { Urban } & 49 & 8(16.3 \%) \\ \text { Water Source } & & \\ \text { Treated water } & 45 & 13(28.9 \%) \\ \text { Untreated water } & 277 & 62(22.4 \%) \\ \text { he placenta and placental fetuses } & & \\ \text { Standard garbage } & 21 & 3(14.3 \%) \\ \text { Environment } & 177 & 45(25.4 \%) \\ \text { Incinerate and bury } & 103 & 22(21.4 \%) \\ \text { Other } & 4 & - \\ \text { Quarantine } & & 8(28.6 \%) \\ \text { Yes } & 28 & 67(22.8 \%) \\ \text { No } & 294 & \end{array}$

Blood samples were collected via an external jugular vein puncture in a vacuum collection system and stored in sterile tubes without the use of an anticoagulant. For the purposes of obtaining sera, samples were centrifuged at $900 \mathrm{~g}$ for 10 minutes and stored in $2 \mathrm{ml}$ polypropylene tubes at $-20^{\circ} \mathrm{C}$ until virus neutralization was performed to screen for equine anti-alphaherpesvirus antibodies (Kotait et al., 1989). The standard viral sample used was A4/72, stored at the Biological Institute of São Paulo (Instituto Biológico de São Paulo) in VERO cells. Blood serum titers (expressed in $\log 10$ ) were considered reactive starting with the lowest dilution (greater than or equal to 4) capable of inhibiting $100 \%$ of the cytopathic effect (CPE).

In order to analyze the association between the reproductive history and alphaherpesvirus infection, a univariate analysis of the variables of interest was performed by Pearson's chi-square, with a statistical significance of 0.05 . The program Epi Info 3.5.2 was used to perform the statistical calculations.

Of the horses screened, 23.3\% (75/322; 95\% CI: $18.9-28.4 \%)$ were found to be reactive to antialphaherpesvirus antibodies. In addition, 61.9\% (26/42) of the farms had at least one reactive animal, with an inter-herd variation of $5 \%$ to $100 \%$. When analyzing reproductive rates, the findings showed an association between herpetic infection and the use of reproductive biology techniques (such as AI and ET) using natural mating $(\mathrm{p}=0.003)$; history of perinatal mortality in the herd $(p=0.004)$; birth interval, mainly over two years $(p=0.003)$; and reproductive seasonality, with the observation of mares that had irregular cycles as compared to rest of the herd $(p=0.041$; Table 2). 
Table 2

Reproductive history in association with herpetic infection in horses in the state of Pernambuco

\begin{tabular}{|c|c|c|c|}
\hline Variable & $\mathrm{N}$ & $\mathrm{VN}$ & $\mathrm{P}$ \\
\hline \multicolumn{4}{|l|}{ Reproductive Techniques } \\
\hline Natural mating & 214 & $39(18.2 \%)$ & 0.003 \\
\hline Biology techniques & 53 & $21(39.6 \%)$ & \\
\hline Natural mating + Biology techniques & 39 & $10(25.6 \%)$ & \\
\hline \multicolumn{4}{|l|}{ Cases of abortions on the farm } \\
\hline Yes & 122 & $41(33.6 \%)$ & 0.000 \\
\hline No & 183 & $29(15.8 \%)$ & \\
\hline \multicolumn{4}{|l|}{ Perinatal mortality } \\
\hline Yes & 63 & $23(36.5 \%)$ & 0.004 \\
\hline No & 244 & $48(19.7 \%)$ & \\
\hline \multicolumn{4}{|l|}{ Fertility rate } \\
\hline 1 foal per year & 122 & $36(29.5 \%)$ & 0.239 \\
\hline 1 foal every 2 years & 25 & $5(20.0 \%)$ & \\
\hline More than 2 years apart & 5 & - & \\
\hline \multicolumn{4}{|l|}{ Average gestation time } \\
\hline 320-335 days & 136 & $41(30.1 \%)$ & 0.004 \\
\hline$>335$ days & 16 & - & \\
\hline \multicolumn{4}{|l|}{ Reproductive seasonality } \\
\hline Mares with regular cycles & 105 & $34(32.4 \%)$ & \\
\hline Mares with irregular cycles & 45 & $6(13.3 \%)$ & 0.041 \\
\hline Young mares that have not menstruated & 2 & $1(50.0 \%)$ & \\
\hline \multicolumn{4}{|l|}{ Birth interval } \\
\hline Annual & 95 & $20(21.1 \%)$ & \\
\hline Between 1 and 2 years & 28 & $6(21.1 \%)$ & 0.003 \\
\hline More than 2 years & 29 & $15(51.7 \%)$ & \\
\hline \multicolumn{4}{|l|}{ Occurrence of assisted births } \\
\hline Yes & 7 & - & 0.106 \\
\hline No & 146 & $41(28.1 \%)$ & \\
\hline
\end{tabular}

VN: virus neutralization.

This is the first report on the detection of horses reactive to anti-alphaherpesvirus antibody screening in the state of Pernambuco, Brazil. According to owner's information, no animals were vaccinated against the etiologic agent, and therefore, all reactions are indicative of natural infection. The occurrence observed is similar to results reported in the southeastern region of the country in the state of São Paulo, where 26\% (42/163) of animals were reactive to anti-alphaherpesvirus antibodies, when applying virus neutralization (Cunha et al., 2009). In the northern region in the state of Rondônia, a similar occurrence was also observed, with $22.7 \%(40 / 176)$ of horses being reactive to antialphaherpesvirus antibodies, when using the virus neutralization technique (Aguiar et al., 2008). 
Although the occurrence observed in this study was not high, there was a high number of farms with positive animals. The cause of this finding may be related to the hygiene and sanitary management adopted by the farms, such as the entry and exit of animals in these regions without quarantine. In addition, horses are raised together with mules and donkeys, highlighting their importance as potential sources of infection for horses (Yildirim, Yilmaz, \& Kirmizigul, 2015).

There was a higher occurrence of herpetic infection in farms that use biological reproductive techniques, such as AI and ET, while using natural mating in the herd $(p=0.003)$. Stallions are often neglected when it comes to vaccination, thus endangering the immunological protection of the herd. The male is also used for genetic improvement of the herd and will come into contact with several females, facilitating the subsequent infection and spread of the virus throughout the herd (AlencarAraripe et al., 2014). The venereal transmission of stallions to females by semen remains unclear; however, Walter et al. (2012) found that $41.6 \%$ $(5 / 12)$ horses tested positive, when using samples of fresh and frozen equine semen, which they correlated with the infectivity of the asymptomatic stallions during febrile peaks in the pathogenic period after viral reactivation. However, this had already been observed after the viremic period (Tearle et al., 1996). Furthermore, it is not possible to conclude whether the venereal transmission of EHV-1 by semen is possible, as with bovine herpesvirus type 1 , since the infected animals were not used for reproduction. There are also no data available on the infective dose needed to cause herpetic infection in the mare by natural mating or AI (Walter et al., 2012).

EHV-1 shows affinity for equine reproductive tissue in both sexes, i.e. endometrium and placenta in mares and epididymis and semen in stallions. Although different viral strains may show different degrees of endothelial tropism, it is known that EHV-1 has high affinity for the pregnant uterus (Gardiner et al., 2012). The process may be facilitated by abnormalities in glycoproteins expressed by endothelial cells of pregnant uteri in later stages of pregnancy. Both interleukin-2 and equine chorionic gonadotropin independently and directly activate latently infected leukocytes (Smith, Iqbal, Edington, Purewal, \& Hamblin, 1998).

Regarding the history of perinatal mortality in the herd, Silva et al. (2018) observed the low occurrence of EHV-1 as a cause of perinatal mortality and abortion in Brazil. Maternal humoral protection associated with increased routine vaccination, as well as improvements in hygienicsanitary management, may have contributed to the low rates of EHV-1 abortion. However, reactivation of the quiescent virus should also be considered. It is noteworthy that vaccination does not guarantee that the mare will avoid abortion, as there are other differential diagnoses that are still prevalent.

Although it is known that a number of factors may interfere with female fertility and potentially cause outbreaks of abortions, no effective long-term losses in reproductive performance of miscarrying mares due to herpetic infection have been found. Mares can normally conceive viable and healthy foals in seasons subsequent to abortions (Schulman, Kass, Becker, \& Van der Merwe, 2013).

Since this disease is considered to be one of the most damaging to equiculture, prevention and control are essential. The ability to establish latency ensures its maintenance in the host (Grinde, 2013). Certain factors associated with the host such as age, physical condition, and immune status should be observed and re-assessed, both in terms of the hygienic-sanitary and reproductive management (Ma et al., 2013).

In this study, horses reactive to antialphaherpesvirus antibody screening were identified and the findings suggest adoption of prophylactic measures such as vaccination of the whole herd for protection of susceptible animals and to reduce the viral load excreted by the animals with latent infection. 


\section{Biosafety \& Research Ethics Committee}

This study was approved by the Animal Research Ethics Committee (CEUA - Comissão de Ética em Uso de Animais) of the Federal Rural University of Pernambuco (UFRPE - Universidade Federal Rural de Pernambuco), under license number 133/2016.

\section{References}

Aguiar, D. M., Cavalcante, G. T., Lara, M. C. C. S. H., Villalobos, E. M. C., Cunha, E. M. S., Okuda, L. H., ... Gennari, S. M. (2008). Prevalência de anticorpos contra agentes virais e bacterianos em equídeos do município de Monte Negro, Rondônia, Amazônia Ocidental Brasileira. Brazilian Journal of Veterinary Research and Animal Science, 45(4), 269-276. doi: 10.11606/1678-4456.2008.26685

Alencar-Araripe, M. G., Maia, D. C. S. C., Campelo, C. C., Silva, A. Jr., Costa e Silva, M., Dias, A. V., . . . Nunes-Pinheiro, D. C. S. (2014). Evidências sorológicas de EHV-1/ EHV-4 em cavalos de vaquejada no estado do Ceará, Brasil. Revista Brasileira de Higiene e Sanidade Animal, 8(2), 203217. doi: 10.5935/1981-2965.2014.0029

Beck, S. L., \& Cintra,A. G. (2011). Treinamento específico e/ou condicionamento físico. In Beck, S. L., \& Cintra, A. G. Manual de gerenciamento equestre (pp. 107147). Produção Independente: Araucária.

Cunha, E. M. S., Villalobos, E. M. C., Nassar, A. F. C., Lara, M. C. C. S. H., Peres, N. F., Palazzo, J. P. C., . . . Pino, F. A. (2009). Prevalência de anticorpos contra agentes virais em equídeos no sul do estado de São Paulo. Arquivos do Instituto Biológico, 76(2), 165171.

Gardiner, D. W., Lunn, D. P., Goehring, L. S., Chiang, Y. W., Cook, C., Osterrieder, N., . . . Hussey, G. S. (2012). Strain impact on equine herpesvirus type 1 (EHV-1) abortion models: viral loads in fetal and placental tissues and foals. Vaccine, 30(46), 65646572. doi: 10.1016/j.vaccine.2012.08.046

Grinde, B. (2013). Herpesviruses: latency and reactivation - viral strategies and host response. Journal of Oral Microbiology, 5(1), 1-9. doi: 10.3402/jom. v5i0.22766

Kotait, I., Peixoto, Z. M. P., Queiroz, L. H., Cunha, E. M. S., Souza, M. C. A. M., Macruz, R., \& Freitas, C. A. (1989). Diagnóstico laboratorial do aborto equino a vírus através de imunofluorescência e soroneutralização. Revista de Microbiologia, 20(1), 128-132.
Ma, G., Azab, W. \& Osterrieder, N. (2013). Equine herpesviruses type 1 (EHV-1) and 4 (EHV-4) Masters of co-evolution and a constant threat to equids and beyond. Veterinary Microbiology, 167(12), 123-134. doi: 10.1016/j.vetmic.2013.06.018

Ministério da Agricultura, Pecuária e Abastecimento. (2016). Revisão do Estudo do Complexo do Agronegócio do Cavalo. Recuperado em 1 de Maio, 2019, de http://www.agricultura.gov.br/assuntos/ camaras-setoriais-tematicas/documentos/camarassetoriais/equideocultura/anos-anteriores/revisao-doestudo-do-complexo-do-agronegocio-do-cavalo

Penkert, R. R. \& Kalejta, R. F. (2011). Tegument protein control of latent herpesvirus establishment and animation. Herpesviridae, 2(3), 1-20. doi: $10.1186 / 2042-4280-2-3$

Schulman, M. L., Kass, P. H., Becker, A., \& Van Der Merwe, B. (2013). A predictive model for reproductive performance following abortion in thoroughbred mares. Veterinary Record, 172(2), 44. doi: 10.1136/vr.100670

Silva,A.A., Cunha, E.M.S.,Lara,M.C.C.S.H., Villalobos, E. M. C., Nassar, A. F. C., Mori, E., . . . Del Fava, C. (2018). Low occurrence of equine herpesvirus 1 (EHV-1) as cause of abortion and perinatal mortality in Brazil. Arquivos do Instituto Biológico, 85(1), 1-7. doi: 10.1590/1808-1657000852017

Smith, D. J., Iqbal, J., Edington, N., Purewal, A., \& Hamblin, A. S. (1998). In vitro reactivation of latent equid herpesvirus-1 from $\mathrm{CD} 5+/ \mathrm{CD} 8+$ leukocytes indirectly by IL-2 or chorionic gonadotrophin. Journal of General Virology, 79(12), 2997-3004. doi: 10.1099/0022-1317-79-12-2997

Tearle, J. P., Smith, K. C., Boyle, M. S., Binns, M. M., Livesay, G. L., \& Mumford, J. A. (1996). Replication of equid herpesvirus-1 (EHV-1) in the testes and epididymis of ponies and venereal shedding of infectious virus. Journal of Comparative Pathology, 115(4), 385-397. doi: 10.1016/S00219975(96)80073-9

Walter, J., Balzer, H. J., Seeh, C., Fey, K., Bleul, U., \& Osterrieder, N. (2012). Venereal shedding of equid herpesvirus-1 (EHV-1) in naturally infected stallions. Journal of Veterinary Internal Medicine, 26(6), 1500-1504. doi: 10.1111/j.1939-1676.2012.00997.x

Yildirim, Y., Yilmaz, V., \& Kirmizigul, A. H. (2015). Equine herpes virus type 1 (EHV-1) and 4 (EHV4) infections in horses and donkeys in northeastern Turkey. Iranian Journal of Veterinary Research, 16(4), 341-344. doi: 10.22099/IJVR.2015.3285 
